\title{
Phytochemical properties and antioxidant activities of the leaf extracts of Boenninghausenia albiflora (Hook.) Rchb. ex. Meisn. (Rutaceae)
}

\author{
I Putu Agus Hendra Wibawa ${ }^{1}$, Putri Sri Andila ${ }^{1}$, Vienna Saraswaty ${ }^{2}$ dan I Gede Tirta ${ }^{1}$ \\ ${ }^{1}$ Research Center of Plant Conservation and Botanic Gardens, Indonesia Institue of Science, Bogor, Indonesia \\ ${ }^{2}$ Research Unit for Clean Technology, Indonesia Institute of Science, Bandung, Indonesia.
}

\begin{abstract}
Boenninghausenia albiflora is a well-known plant for being used in various traditional treatments. The plant is also reported to contain an essential oil which has a distinctive and pungent aroma. The present study aimed at investigating extraction yields, phytochemical compounds and antioxidants, and potential uses of $B$. albiflora leaves extracted with acetone solvent. Bioactive compounds of the leaf extract of $B$. albiflora were identified by GCMS analysis while the antioxidant assay was measured by DPPH method. The extract obtained from acetone contained 30 compounds including coumarin group, 2-Isoprenyl-2,3-dihydro-furo [3,2-G] chromen-7-one (22.89\% w/v) as the highest percentage compound. Other coumarins such as suberosin and dehydrogeijerin were also identified in this study. The $\mathrm{IC}_{50}$ values of the leaves extract of $B$. albiflora was 194.3 ppm which was higher than propyl gallate. Thus indicating $B$. albiflora as potential sources of anti-cancer, anti-inflammatory and antioxidant.
\end{abstract}

Keywords: Anti-cancer, anti-inflammation, antioxidant, Boenninghausenia albiflora, chemical compounds.

Received: 16 January 2020 Revised: 26 February 2020 Accepted: 20 March 2020

\section{Introduction}

Boenninghausenia albiflora (Hook.) Rchb. ex Meisn. is a monotypic genus belong to Rutaceae family. This deciduous shrub is thought to be native of the Indian region and distributed to the Southeast and Southwest of China (Takhtajan, 1986). This species can grow in tropical to sub-tropical regions with an altitude of 500 3000 meter above the sea level. B. albiflora is found growing in Bhutan, Nepal, Pakistan, Kashmir, India, Indonesia, Philippines, Myanmar, Thailand, Laos, North Vietnam, China and Japan (Flora of China, 2016).

Traditionally $B$. albiflora has been used for several medicinal purposes, such as a wound remedy, treatment of bleeding, and infection (Medicinal Herbs, 2016; Tirta et al., 2015). The leaf squash of B. albiflora can also be utilized to treat skin diseases. While all parts of this species can be used to relieve headaches by placing them under a pillow during sleeping (Medicinal Herbs, 2016). Whereas the boiled root is used to treat malaria (Tirta et al., 2015).

The information about phytochemical compounds of B. albiflora essential oils and their potential has been reported several times. Padalia et al. (2012) had revealed about chemical composition of leaf and root essential oils of B. albiflora from Northern India. They found that the

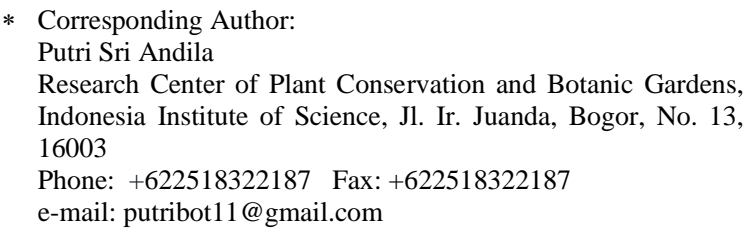

leaf essential oil $B$. albiflora contained dominant compounds $\beta$-myrcene, $(Z)$ - $\beta$-guaiene, $(Z)-\beta$-ocimene and $\beta$ caryophyllene, whereas the root essential oil contained bicyclogermacrene, $\alpha$-terpinyl acetate, geijerene and $\beta$ copaene- $4 \alpha$-ol. It has also been reported that $B$. albiflora leaves contain essential oils with a distinctive and pungent aroma which potential use as anti-microbial, antioxidant, anti-inflammatory, anti-proliferation, natural fragrance, and aromatherapy (Wibawa et al, 2019). While Mehmood et al. (2017) found that the essential oil of $B$. Albiflora has potentials as an hepatoprotective and an antidiabetic agent base on in vivo study.

Although several studies of the B. albiflora essential oil have been carried out, but the studies of the chemical properties and potential of the B. albiflora extract are still very rarely reported in the scientific journal. Therefore, this topic will be very interesting to study. So the aim of this study was to observe the chemical content of acetone extract of $B$. albiflora from Bedugul Bali and to examine its chemical constituents and determine its potential for human uses.

\section{Method}

\section{Plant Material}

The mature leaves of B. albiflora was obtained from the Plant Collection of Bali Botanic Garden (Fig. 1). This species was collected from the Mount Rinjani National Park, Lombok Island, West Nusa Tenggara in 2014 and planted in the Bali Botanic Garden in the same year. Determination of plant species was carried out by Ida Bagus 
Ketut Arinasa as a taxonomist of Bali Botanic Garden Herbarium.

\section{Preparation of Plant Extract}

The fresh and mature leaves of B. albiflora were harvested and separated from the stem and branches. The leaves were dried by avoiding direct sunlight for several days (more or less 5 days or until the leaf completely dried) in the room temperature and avoided from the direct sunlight. A total of $100 \mathrm{~g}$ dried leaves was mashed with a blender and extracted by maceration method with acetone solvent (100 g material in $1000 \mathrm{ml}$ methanol) for $72 \mathrm{~h}$. The extract solution was filtered using the Whatman filter paper and evaporated by using Vacuum Rotary Evaporator IKA-RV10. The evaporated extract was analyzed with GC-MS to determine the phytochemical compounds.

\section{GC-MS Analysis}

The acetone extract of $B$. albiflora was analyzed by GC-MS equipment Merk Shimadzu QP 2010. A total of 1 $\mu \mathrm{L}$ extract was injected to column RTx $5 \mathrm{MS}$ (60 m x $0.25 \mathrm{~mm}$ ) with film thickness $0.25 \mu \mathrm{m}$, oven temperature was programmed between $50-280{ }^{\circ} \mathrm{C}$ at a rate of temperature rise $5^{\circ} \mathrm{C} / \mathrm{min}$, the carrier gas used was Helium with pressure $101 \mathrm{kPa}$, total flow rate $46.5 \mathrm{~mL} / \mathrm{min}$, column flow rate $0.85 \mathrm{~mL} / \mathrm{min}$, cleaning flow rate $3.0 \mathrm{~mL} / \mathrm{min}$ and split ratio 1:50. The chemical components were determined by comparing the spectral data and retention time of GC-MS analysis result with the recorded data in the computer library WILEY7.LIB.

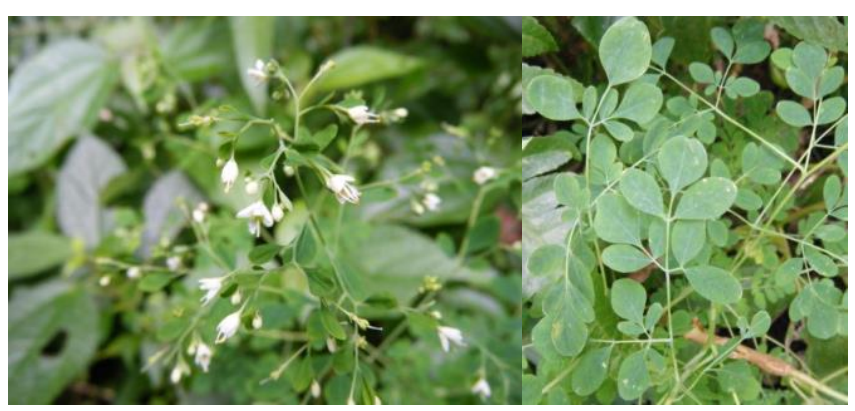

Figure 1. Flowers and Leaves of B. albiflora

\section{2,2-Diphenyl-1-picrylhydrazil (DPPH) assay}

The DPPH assay was conducted using the method from Widowati et al. (2017) with some modification to determine antioxidant activity. A series of concentrations of the leaves extract of $B$. Albiflora $(50,75,100,200$, and
$300 \mathrm{ppm}$ ) were used to make a linearity regression of DPPH scavenging activity. Briefly, $1 \mathrm{~mL}$ of the leaves extracts of $B$. albiflora were put in a bottle glass, then they were added with $4 \mathrm{~mL}$ DPPH (Sigma Aldrich D9132, USA 40ppm in methanol). These mixtures were incubated in dark place for $30 \mathrm{~min}$, and measured the absorbances by spectrophotometer Thermo Scientific Genesys 30 with $517 \mathrm{~nm}$ wavelength. The radical scavenging activity was calculated using the formula:

$$
\text { Scavenging Activity } \%=(\text { Ac }- \text { As }) / A c \times 100
$$

Ac: control absorbance (without sample)

As: sample absorbance

The linearity regression graph of scavenging activity was made by Microsoft excel. The IC50 (Half concentration of inhibition) value was measured by the regression formula. IC50 is the concentration required to result in a 50\% antioxidant activity. The smaller the IC50 value means that the content of antioxidant compounds contained in plant extracts is higher and the antioxidant activity is higher.

\section{Result}

Based on the GC-MS analysis, acetone extract of $B$. albiflora leaves contained 29 identified chemical compounds. The identified chemical compounds and the chromatogram of GC-MS analysis in acetone extract of $B$. Albiflora were performed in table 1 and figure 2 . the major components of the B. albiflora leaves extract were 2Isoprenyl-2,3-dihydro-furo [3,2-G] Chromen-7-one $(22.89 \% \mathrm{w} / \mathrm{v})$.

The GCMS analysis result also showed that acetone extract of $B$. albiflora leaves contained several compounds with a relative concentration more than $2 \%$ (Figure 3.). They were formamide $(3.27 \%)$, Acetid Acid (2.02\%), 2,3-Dihidro-benzofuran $\quad(4.41 \%)$, 9,12,15Octadecatrien-1-ol (2.11\%), 2-Isopropenyl-2,3-DihydroFuro[3,2-G]Chromen-7-One (22.89\%), Suberosin (2.37\%), 2H,6H-Benzo[1,2-b:5,4-b']dipyran-2,6-dione, 7,8-dihydro-8,8-dimethyl- $(5.45 \%)$, Bravelin (2.49\%), Dehydrogeijerin (4.57\%), 3-hydrocarbonyl-5-hydroxy-7(5.37\%), 9-Dehydro-1-Methyl Estrone Methyl Ether $(3.43 \%)$ and 17.beta.,19-Diacetoxy-4,4-dimethyl13.alpha.-androsta-5,7-dien-3-one $\quad(5.87 \%)$ (sorted by retention time).

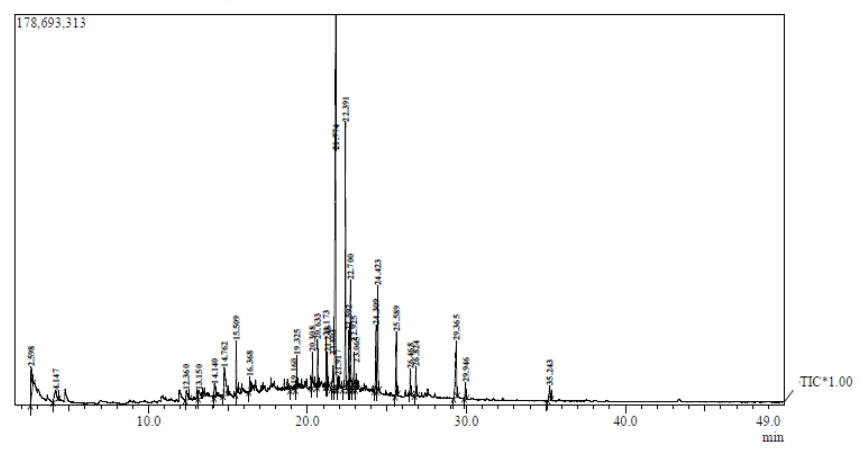

Figure 2. The Chromatogram of GC-MS analysis in acetone extract of B. Albiflora 
Table 1. The GC-MS analysis results in acetone extract of B. albiflora leaves

\begin{tabular}{|c|c|c|c|c|}
\hline Peak\# & R.Time & Area & Conc\% & Name \\
\hline 1 & 2.598 & 76304731 & 3.27 & Formamide (CAS) Methanamide \\
\hline 2 & 4.147 & 46967133 & 2.02 & Acetic acid (CAS) Ethylic acid \\
\hline 3 & 12.360 & 29646258 & 1.27 & 2-Cyclopenten-1-one, 2-hydroxy-3-methyl- (CAS) Corylon \\
\hline 4 & 13.150 & 31493640 & 1.35 & Phenol, 3-methyl- (CAS) m-Cresol \\
\hline 5 & 14.140 & 27433184 & 1.18 & Phenol, 3-ethyl- (CAS) m-Ethylphenol \\
\hline 6 & 14.762 & 102715001 & 4.41 & 2,3-Dihydro-Benzofuran \\
\hline 7 & 15.509 & 46115806 & 1.98 & 7-Cyano(15n)-Cycloheptatriene \\
\hline 8 & 16.368 & 23175873 & 0.99 & $\begin{array}{l}\text { D-Glucose, 4-O-[3-acetyl-1-(trimethylsilyl)-1H-indolyl]-2,3,5,6-tetrakis-O- } \\
\text { (trimethylsilyl }\end{array}$ \\
\hline 9 & 19.160 & 22953253 & 0.98 & 1,2-Benzenediol, 4-(2-amino-1-hydroxyethyl)-, (R)- (CAS) .alpha.-(aminomethyl) \\
\hline 10 & 19.325 & 31449700 & 1.35 & 1-Hexadecyne (CAS) \\
\hline 11 & 20.308 & 45540764 & 1.95 & Hexadecanoic acid (CAS) Palmitic acid \\
\hline 12 & 20.633 & 45119964 & 1.94 & 4-Cyanophenyl 4-Propylbenzoate \\
\hline 13 & 21.173 & 37612686 & 1.61 & Seselin \\
\hline 14 & 21.248 & 28243944 & 1.21 & 2-Propenoic acid, 3-[4-[(3-methyl-1-butenyl)oxy]phenyl]-, methyl ester (CAS) \\
\hline 15 & 21.603 & 49184085 & 2.11 & 9,12,15-Octadecatrien-1-ol (CAS) octadeca-9,12,15-trien-1-ol \\
\hline 16 & 21.774 & 533368939 & 22.89 & 2-isopropenyl-2,3-dihydro-furo[3,2-g]chromen-7-one \\
\hline 17 & 21.917 & 27538821 & 1.18 & Hexadecanamide (CAS) Amide 16 \\
\hline 18 & 22.391 & 282971684 & 12.14 & - \\
\hline 19 & 22.592 & 55303249 & 2.37 & Suberosin \\
\hline 20 & 22.700 & 127081671 & 5.45 & 2H,6H-Benzo[1,2-b:5,4-b']dipyran-2,6-dione, 7,8-dihydro-8,8-dimethyl- (CAS) \\
\hline 21 & 22.925 & 58107110 & 2.49 & Bravelin \\
\hline 22 & 23.065 & 24988623 & 1.07 & Isopimpinellin \\
\hline 23 & 24.309 & 106417774 & 4.57 & Dehydrogeijerin \\
\hline 24 & 24.423 & 125121538 & 5.37 & $\begin{array}{l}\text { 3-hydroxycarbonyl-5-hydroxy-7-pentyl-9-oxa-10,10-dimethyl-1,2,4a,10a- } \\
\text { tetrahydrophenanthrane }\end{array}$ \\
\hline 25 & 25.589 & 79950075 & 3.43 & 9-dehydro-1-methyl estrone methyl ether \\
\hline 26 & 26.468 & 28393768 & 1.22 & Triacontane (CAS) n-Triacontane \\
\hline 27 & 26.824 & 37704863 & 1.62 & Cyclohexanol, 5-methyl-2-(1-methylethyl)-, acetate (CAS) Menthol acetate \\
\hline 28 & 29.365 & 136747775 & 5.87 & 17.beta.,19-Diacetoxy-4,4-dimethyl-13.alpha.-androsta-5,7-dien-3-one \\
\hline 29 & 29.946 & 26650801 & 1.14 & Pentatriacontane (CAS) n-Pentatriacontane \\
\hline \multirow[t]{2}{*}{30} & 35.243 & 36207845 & 1.55 & Pentatriacontane (CAS) n-Pentatriacontane \\
\hline & & 2330510558 & $\mathbf{1 0 0 . 0 0}$ & \\
\hline
\end{tabular}

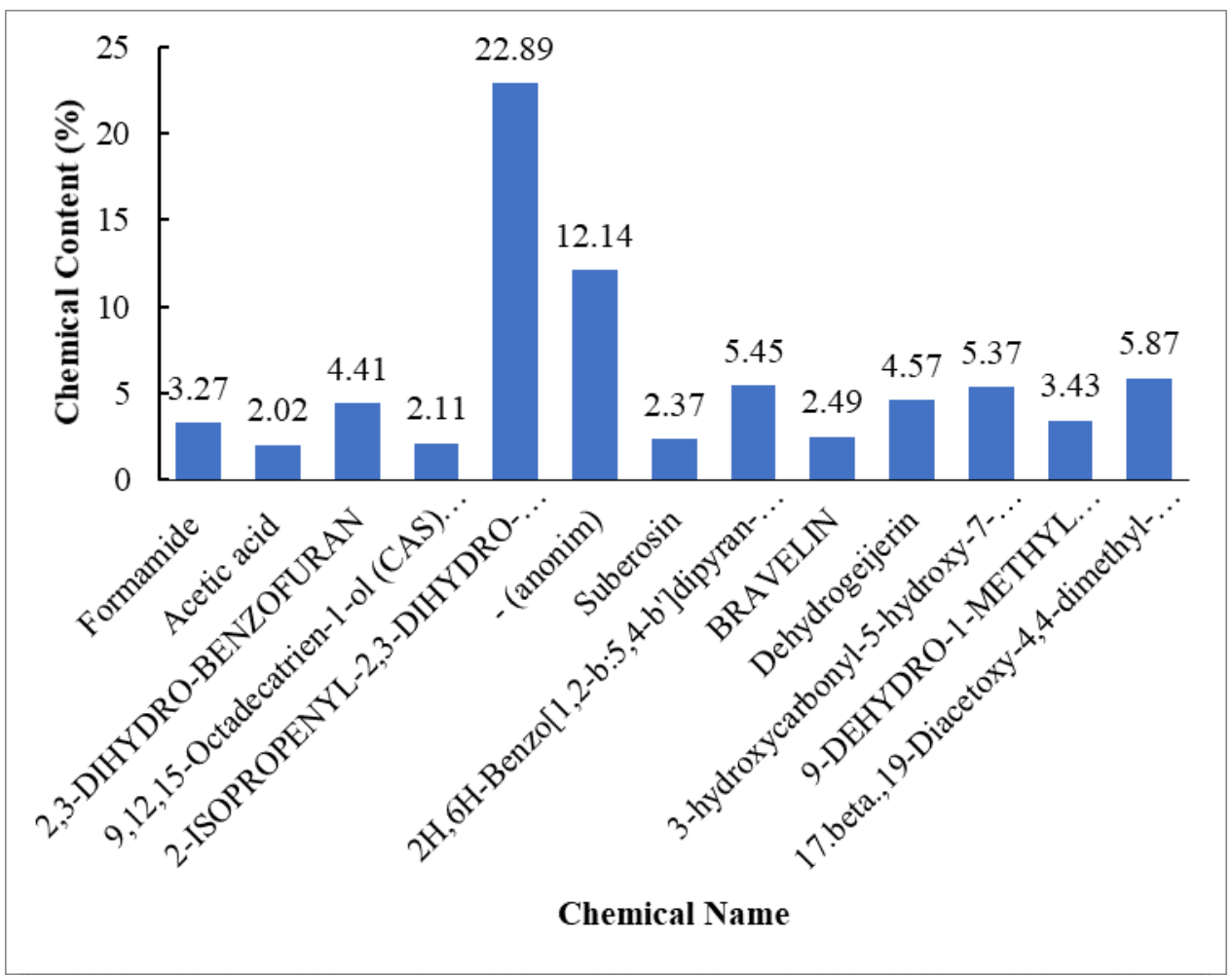

Figure 3. The chemical contents of acetone extract of B. albiflora with relative concentration more than $2 \%$ 


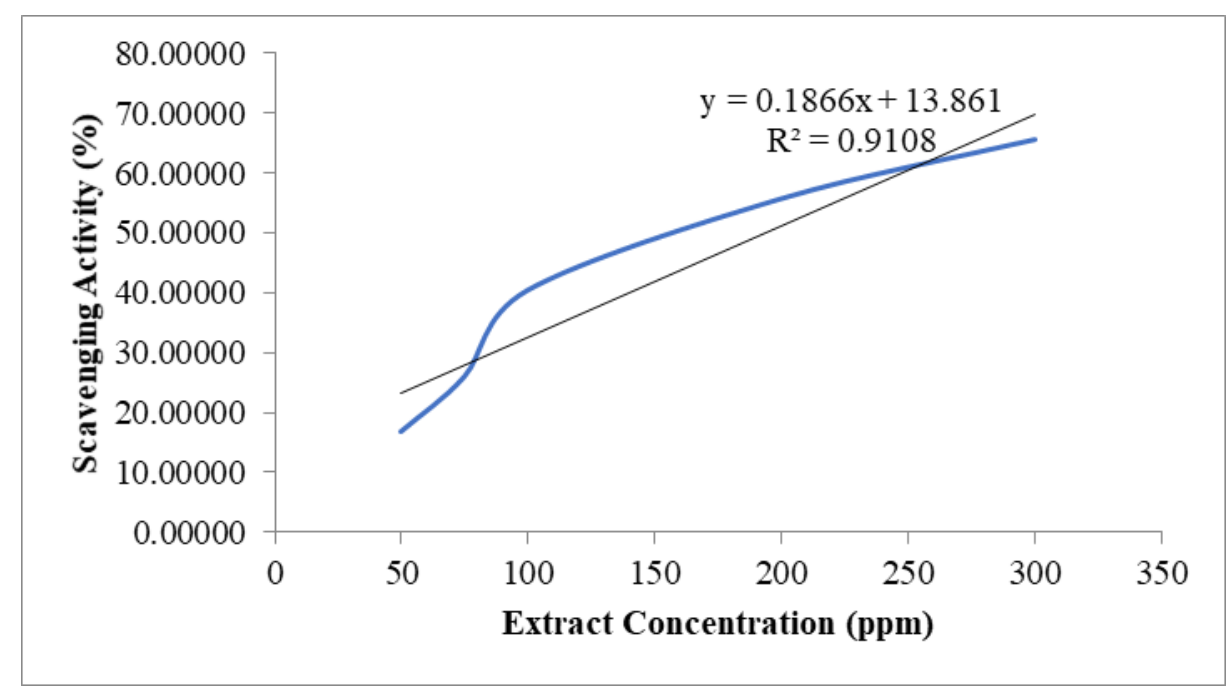

Figure 4. The regression graph of DPPH scavenging activity percentage of the leaves extract of B. albiflora

\section{2,2-Diphenyl-1-picrylhydrazil (DPPH) assay}

The values of the percentage of the free radical scavenging activity of leaves extract of $B$. albiflora in different concentration was exhibited in table 2 . and its regression graph was showed in figure 4. DPPH assay showed that the IC50 value of the leaves extract of $B$. albiflora was 194.30 ppm.

Table 2. the percentage of DPPH scavenging activity of leaves extract of $B$. albiflora in different concentration

\begin{tabular}{cc}
\hline ppm & \% Scavenging activity \\
\hline 50 & 16.73640 \\
75 & 25.94142 \\
100 & 40.44630 \\
$\mathbf{1 9 4 . 3 0}$ & $\mathbf{5 0}(\mathbf{I C ~ 5 0 )}$ \\
200 & 55.78801 \\
300 & 65.69038 \\
\hline
\end{tabular}

\section{Discussion}

The results exhibited that the dominant contents of the leaves extract of $B$. albiflora was 2-Isoprenyl-2,3dihydro-furo [3,2-G] Chromen-7-one $(22.89 \% \mathrm{w} / \mathrm{v})$, a chemical compound belong to the coumarin group. It has been reported that coumarin group posses various pharmacology activities such as antioxidant, Antiinflammatory, anti-bacterial, anti-hyperglycemic, antiadipogenic and anticancer (Tavares da Silva et al., 2019), insecticides (insect poisons), antiplatelet (drugs to prevent the formation of blood clots, useful for treating heart disease), antiplasmodial (antimalarial), antifeedant (food inhibitors, in insects) and growth inhibitory properties (Bhattacharya et al., 1989; Co et al., 1990; Escoubas et al., 1992; Gaur, 1999; Oketch-Rabah et al., 2000). The majority of coumarin compounds can be extracted using acetone solvents. B. albiflora belong to Rutaceae family and majority of Rutaceae family members are known for their ability to produce a variety of coumarin natural products (Barik et al., 1983; Chen et al., 1995; Ishii et al., 1993; Reisch and Achenbach, 1989). According to
Sharma et al. (2006) ethanol extracts of B. albiflora showed insecticide activity against several forest plant pests. Coumarin compounds isolated from Murraya exotica were also reported to have insecticide activity against a number of pest species (Barik \& Kundu, 1987). In addition, this extract also contains other identified coumarin compounds such as Suberosin $(2.37 \% \mathrm{w} / \mathrm{v})$ and Dehydrogeijerin $(4.57 \% \mathrm{w} / \mathrm{v})$. Both of these compounds are known to have anti-cancer and anti-inflammatory activity (Chen et al., 2007; Deok et al., 2012).

This study also revealed that the acetone extract of $B$. albiflora leaves contained 12 chemical components with relative concentration more than $2 \%$ and some other compounds which relative concentrations are less than $2 \%$ but have potential use for industry and pharmacology. Such as Formamide. This compound is also known as methanamide.it is present in small amounts in acetone extract of $B$. albiflora leaves $(3.27 \% \mathrm{w} / \mathrm{v})$. This compound is an amide derived from formic acid. Formamide is a clear liquid that is soluble in water and has an ammonia-like odor. Formamide is a chemical raw material for the manufacture of sulfa drugs, other medicines, herbicides, pesticides and manufacturing of hydroxylic acid. Formamide is used as a softener for paper and fiber and as a solvent for many ionic compounds and also as resins and plasticizers (Hohn, 1999).

Acetic acid is contained in an amount of $2.02 \% \mathrm{w} / \mathrm{v}$ in the acetone extract of $B$. albiflora leaves. This compound has many functions, but most are used as chemical reagents, fungicides, herbicides, microbiosides, $\mathrm{pH}$ adjusters and solvents in various industries, such as food, agriculture, cleaning and cosmetics. Injection of acetic acid into tumor has been used to treat cancer since the 1800s (Shibata, 1998). Acetic acid is used as part of cervical cancer screening in many regions in developing countries (Domgue et al., 2015). Acetic acid is an effective antiseptic with a broad spectrum of activity against streptococci, staphylococci, pseudomonas, enterococci, etc. (Madhusudhan, 2015; Ryssel et al., 2009). Acetic acid is 
also used to treat skin infections caused by pseudomonas strains that are antibiotics resistant (Nagoba et al., 2013).

B. albiflora leaf extract also contained Pentatriacontane as much as $2.69 \%$. Pasdaran et al. (2018) reported that the Pentatriacontane compounds contained in Scrophularia amplexicaulis and Scrophularia oxysepala had antibacterial activity against Streptococcus aureus. Menthol acetate was another compound found in this extract $(1.62 \% \mathrm{w} / \mathrm{v})$. Previous study revealed that menthol acetate had effect of reducing mild pain caused by muscle strains or sprains, backaches, bruises, and cramps. Menthol was a topical analgesic that worked by temporarily relieving mild pain. Menthol also had antiseptic properties that could inhibit germs (Sumardjo, 2006). Triakontanol also existed in the amount of $1.22 \% \mathrm{w} / \mathrm{v}$. Ries (1985) reported that Triacontanol had the potential to increase the citrus production and increase the ration of sugar to acid in citrus plant, but the work mechanism had not been fully known. Triacontanol could also increase Camellia sinensis tea production (Karssen et al., 1992).

Hexadecanoic acid or Palmitic acid presented in small amount $(1.95 \% \mathrm{w} / \mathrm{v})$. This chemical compound is a saturated fatty acid commonly found in palm oil. Palmitic acid is often used in the beauty industry as a component of soaps and other cleaning products because it has surfactant properties. Palmitic acid is also an excellent emollient that has potential to maintain the natural moisture and to smooth the skin (Sumardjo, 2006).

1-Hexadecyne and $\mathrm{m}$-Cresol were found in the acetone extract of $B$. albiflora leaves as much as $1.35 \% \mathrm{w} / \mathrm{v}$. According to Selvi and Basker (2012) 1-Hexadecyne had antibacterial properties. m-Cresol $(1.35 \%)$ is a precursor of various active compounds such as pesticides (phenitrothion and fenthion), synthetic vitamin E (Mukhopadhyay, 2004), and antiseptics (such as amylmetacresol) (Morrell, 2003). As for the other compounds contained in this extract have not been studied in biological activity.

\section{Antioxidant Assay}

By comparing the IC50 Value of the leaves extract of $B$. albiflora $(194.30 \mathrm{ppm})$ with the other members in Rutaceae family, the IC 50 value of $B$. albiflora can be categorized as a high category. Momeni et al. (2010) reported that IC50 value of Vepris heterophylla R. Letouzey was 204.69 ppm. They claimed that this species might be a good source of an antioxidant because it exhibited high free radical scavenging activities. While Kassim et al. (2013) found that the IC50 of methanol extract of Bark of Melicope glabra (Rutaceae) was found $810.02 \mathrm{ppm}$. The IC50 of both species in Rutaceae Family was lower than the IC50 of $B$. albiflora leaves extract. It means, $B$. abliflora leaf contains antioxidants in quite high amounts and has potential to be a new source of the exogenous antioxidant. The exogenous antioxidant was an important component to ameliorate the damage in human body caused by oxidative stress. Antioxidant compounds can inhibite he initiation or propagation of oxidative chain reaction, playing a rule as free radical scavengers, quenchers of singlet oxygen and reducing agents (Tan et al., 2018).
In conclusion, acetone extract of $B$. albiflora leaves was dominated by coumarin compounds. B. albiflora leaf was suspected having potential as an anti-cancer and antiinflammatory agents because it contained Suberosin and Dehidrogeijerin compounds. B. albiflora leaf extract also had various other potential as an antioxidant, insecticide, antimalarial agent and preventing the blood clots.

\section{Acknowledgment}

This research was funded by DIPA “Eka Karya” Botanical Garden, Indonesian Institute of Science. Authors declared that I Putu Agus Hendra Wibawa and Putri Sri Andila were the main contributors in this paper, while Vienna Saraswaty and I Gede Tirta were the member contributors.

\section{References}

Barik, B. R., Dey, A. K. \& Chatterjee, A. (1983). Murrayatin, a coumarin from Murraya exotica. Phytochemistry, 22(10), 2273-2275. doi:10.1016/S0031-9422(00)80160-0

Bhattacharya, L., Mukhopadhyay, M. \& Chakraborty, D. P. (1989). 3(1',1'- Dimethyl allyl) xanthylentin and scopoletin, two plant growth inhibitors from Murraya koenigii. Plant Physiology \& Biochemistry (New Delhi), 16(1), 23-26.

Chen, I. H. S., Lin, C. Y., Tsai, I., Ishikawa, T., \& Ishii, H. (1995). Coumarins and anti-platelet aggregation constituents from Zanthoxylum schinifolium. Phytochemistry, 39(5), 1091-1097. doi:10.1016/0031-9422(95)00054-b

Chen, Y. C., Tsai, W. J., Wu, M. H., Lin, L. C., \& Kuo, Y. C. (2007) Suberosin inhibits proliferation of human peripheral blood mononuclear cells through the modulation of the transcription factors NF-AT and NF-kB, British Journal of Pharmacology, 150(3), 298-312. doi: 10.1038/sj.bjp.0706987

Deok, S. B., Chul, Y. K., \& Jae, K. L. (2012). Anti-inflammatory effects of dehydrogeijerin in LPS-stimulated murine macrophages, International Immunopharmacology, 734-739. doi:10.1016/j.intimp.2012.10.009

Domgue, F. J., Combescure, C., Fokom-Defo, V., Tebeu, P. M., Vassilakos, P., Kengne, A. P., \& Petignat, P. (2015). Performance of alternative strategies for primary cervical cancer screening in sub-Saharan Africa: systematic review and meta-analysis of diagnostic test accuracy studies". BMJ (Clinical Research Ed.), 351, h3084. doi:10.1136/bmj.h3084

Escoubas, P, Fukushi, Y, Lajide, L \& Mizutani J. (1992). A new method for fast isolation of insect antifeedant compounds from complex mixtures. Journal of Chemical Ecology 18(10), 1819-1832. doi:10.1007/BF02751106

Flora of China (2016). Boenninghausenia albiflora. Flora of China (Vol. 11, pp. 73). Retrieved from: http://www.eflo ras.org/florataxon.aspx?flora_id=2\&taxon_id=200012427

Gaur, R. D. (1999). Flora of the District Garhwal Northwestern Himalaya (with ethnobotanical notes). Srinagar, Garhwal, India: Transmedia Publishers

Hohn, A. (1999). "Formamide". In Kroschwitz, J. I. (ed.). Kirk-Othmer Concise Encylclopedia of Chemical Technology (4th ed., pp. 943-944). New York, NY: John Wiley \& Sons, Inc.

Ishii, H., Kobayashi, J., Yamaguchi, K. \& Ishikawa, T. (1993). Toddalosin, a new biscoumarin from Toddalia asiatica. Chemical and Pharmautical Bulletine, 41(9), 1655-1656.

Jaelani. (2009). Aromaterapi. Jakarta: Pustaka Populer Obor

Karssen, C. M., Loon, L. C., \& Vreugdenhil D. (1992). Current Plant Science and Biotechnology in Agriculture: Progress in Plant Growth Regulation. Dordrecht: Kluwer Academic Publishers.

Kassim, N. K., Rahmani, M., Ismail, A., Sukari, M. A., Ee, G. C., Nasir, N. M., \& Awang, K. (2013). Antioxidant activity-guided separation of coumarins and lignan from Melicope glabra (Rutaceae). Food Chemistry, 139(1-4), 87-92. doi:10.1016/j.foodchem.2013.01.108

Ko, F. N., Chen, I. S., Wu, S. J., Lee, L. G., Haung, T. F., \& Teng, C. M. (1990). Antiplatelet effects of chelerythrine chloride isolated from Zanthoxylum simulans. Biochimica et Biophysica Acta - 
Molecular Cell Research, 1052, 360-365. doi:10.1016/01674889(90)90144-3

Madhusudhan, V. L. (2015). Efficacy of 1\% acetic acid in the treatment of chronic wounds infected with Pseudomonas aeruginosa: prospective randomised controlled clinical trial. International Wound Journal, 13(6): 1129-1136. doi:10.1111/iwj.12428

McKenzie, H., Boughton, M., Hayes, L., \& Forsyth, S. (2008) Explaining the complexities and value of nursing practice and knowledge. In I. Morley \& M. Crouch (Eds.), Knowledge as value: Illumination through critical prisms (pp. 209-224). Amsterdam, Netherlands: Rodopi.

Medicinal Herbs. 2016. Boenninghausenia albiflora. Natural. Retrived from : http://www.naturalmedicinalherbs.net/herbs/b/boenning hausenia-albiflora.php

Mehmood, F., Shahzadi, P., Kahn, Z. D., Arshad, N., Bilal, M., Perveen, Z. \& Rizwan, M. (2017). In vivo hepatoprotective and antidiabetic activities of essential oils from Boenninghausenia albiflora (Hook.) reichb. ex heynkh, of Pakistan. MOJ Bioequivalence \& Bioavailability, 4(1):211-214. doi:10.15406/mojbb.2017.04.00060

Momeni, J., Djialeu Ntchatchoua, W. P., Fadimatou, Akam, M. T., \& Ngassoum, M. B. (2010). Antioxidant activities of some cameroonian plants extracts used in the treatment of intestinal and infectious diseases. Indian Journal of Pharmaceutical Sciences, 72(1), 140-144. doi:10.4103/0250-474X.62236

Morrell, D. G. (2003). Catalysis of Organic Reactions. New York: Marcel Dekker, Inc.

Mukhopadhyay, A. K. (2004). Industrial Chemical Cresols and Downstream Derivatives. New York. CRC Press.

Nagoba, B. S., Selkar, S. P., Wadher, B. J., \& Gandhi, R. C. (2013). A Review: Acetic acid treatment of pseudomonal wound infections. Journal of Infection and Public Health, 6(6): 410-415. doi:10.1016/j.jiph.2013.05.005

Oketch-Rabah, H. A., Mwangi, J. W., Lisgarten, J., \& Mberu, E. E. (2000). A new antiplasmodial coumarin from Toddalia asiatica roots. Fitoterapia, 71, 636-640. doi:10.1016/s0367$326 x(00) 00222-7$

Pasdaran, A., Pasdaran, A., Atanassova, M., \& Ahmad, M.A. (2018) Chemical compounds, antibacterial and insecticidal activity of lipophilic extract of Scrophularia amplexicaulis Benth and Scrophularia oxysepala Boiss. Der Pharma Chem, 10(4), 8488.

Reisch, J., \& Achenbach, S. H. (1989). Die wurzelcumarine von Skimmia japonica oblata. Pharmazie, 44, 650.

Sharma, R., Negi, D. S., Shiu, W. K. P., \& Gibbons, S. (2006). Characterization of an insecticidal coumarin from Boenninghausenia albiflora. Phytotherapy Research. 20(7), 607-609. doi:10.1002/ptr.1909

Ries, S. K. (1985). Regulation of plant growth with triacontanol. Critical Reviews in Plant Science, 2(3), 239-285.

Rizal, M., Rusli, M. S., \& Mulyadi, A. (2009). Minyak Atsiri Indonesia. Bogor: IPB

Ryssel, H., Kloeters, O., Germann, G., Schäfer, T. H., Wiedemann, G., \& Oehlbauer, M. (2009). The antimicrobial effect of acetic acid-an alternative to common local antiseptics. Journal of the International Society for Burn Injuries, 35 (5), 695-700.

Selvi, V. S. \& Basker, A. (2012). Phytochemical analysis and GC-MS profiling in the leaves of Sauropus androgynus (L) Merr. International Journal of Drug Development and Research, 4(1), 162-167.

Shibata, N. (1998). Percutaneous ethanol and acetic acid injection for liver metastasis from colon cancer. Gan to Kagaku Ryoho, I(5): 751-755.

Sumardjo, D. (2006). Pengantar Kimia: Buku Panduan Kuliah Mahasiswa Kedokteran. Jakarta: EGC.

Tan, B. L., Norhaizan, M. E., Liew, W. P. P. \& Rahman, H. S. (2018) Antioxidant and oxidative stress: a mutual interplay in agerelated diseases. Frontiers in Pharmacology, 9: 1162. doi:10.3389/fphar.2018.01162

Takhtajan, A. (1986). The Floristic Region of the World. California: University of California Press.

Tavares da Silva, M. L., Bernardo, M. L. S., Singh, J., \& Fernanda de Mesquita, M. (2019). Beneficial Uses of Cinnamon in Health and Diseases: An Interdisciplinary Approach. In Singh, R. B., Watson, R. R., Takahashi, T. (Eds) The Role of Functional Food Security in Global Health (pp. 565-576). US: Elsevier, Academic Press.

Tirta, I. G., Arinasa, I. B. K., Wibawa, I. P. A. H., Peneng, I. Y., \& Suja, I. M. (2015). Eksplorasi Tumbuhan yang Berpotensi Sebagai Penghasil Minyak Atsiri di Sumbawa-NTB. UPT. Balai Konservasi Tumbuhan Kebun Raya 'Eka Karya' Bali. (Unpublished).

Wibawa, I. P. A. H., Saraswaty, V., \& Sujarwo, W. (2019). Studi potensi minyak atsiri daun Boenninghausenia albiflora (Hook.) Rchb. ex Meisn. di Bali. Buletin Kebun Raya, 22(2), 157-166

Widowati, W., Rani, A. P., Hamzah, R. A., Arumwardana, S., Afifah, E., Kusuma, H. S. W., Rihibiha, D. D., Nufus, H., \& Amalia, A. (2017). Antioxidant and antiaging assays of Hibiscus sabdariffa extract and its compounds. Natural Product Sciences, 23(3), 192-200. doi:10.20307/nps.2017.23.3.192 